\title{
Present-day stresses, seismicity and Neogene-to-Recent tectonics of Australia's 'passive' margins: intraplate deformation controlled by plate boundary forces
}

\author{
RICHARD R. HILLIS ${ }^{1}$, MIKE SANDIFORD ${ }^{2}$, SCOTT D. REYNOLDS ${ }^{1,3}$ \\ \& MARK C. QUIGLEY ${ }^{2}$ \\ ${ }^{1}$ Australian School of Petroleum, University of Adelaide, SA 5005, Australia, \\ (e-mail: richard.hillis@adelaide.edu.au) \\ ${ }^{2}$ School of Earth Sciences, University of Melbourne, Victoria 3010, Australia \\ ${ }^{3}$ Present address: Schlumberger Oilfield Services, Abu Dhabi, United Arab Emirates
}

\begin{abstract}
Neogene-to-Recent deformation is widespread on and adjacent to Australia's 'passive' margins. Elevated historical seismic activity and relatively high levels of Neogene-to-Recent tectonic activity are recognized in the Flinders and Mount Lofty Ranges, the SE Australian Passive Margin, SW Western Australia and the North West Shelf. In all cases the orientation of palaeostresses inferred from Neogene-to-Recent structures is consistent with independent determinations of the orientation of the present-day stress field.

Present-day stress orientations (and neotectonic palaeostress trends) vary across the Australian continent. Plate-scale stress modelling that incorporates the complex nature of the convergent plate boundary of the Indo-Australian Plate (with segments of continent-continent collision, continent-arc collision and subduction) indicates that present-day stress orientations in the Australian continent are consistent with a first-order control by plate-boundary forces. The consistency between the present-day, plate-boundary-sourced stress orientations and the record of deformation deduced from neotectonic structures implicates plate boundary forces in the ongoing intraplate deformation of the Australian continent.

Deformation rates inferred from seismicity and neotectonics (as high as $10^{-16} \mathrm{~s}^{-1}$ ) are faster than seismic strain rates in many other 'stable' intraplate regions, suggestive of unusually high stress levels imposed on the Australian intraplate environment from plate boundary interactions many thousands of kilometres distant. The spatial overlap of neotectonic structures and zones of concentrated historical seismicity with ancient fault zones and/or regions of enhanced crustal heat flow indicates that patterns of active deformation in Australia are in part, governed, by prior tectonic structuring and are also related to structural and thermal weakening of continental crust. Neogene-to-Recent intraplate deformation within the Australian continent has had profound and under-recognized effects on hydrocarbon occurrence, both by amplifying some hydrocarbonhosting structures and by inducing leakage from pre-existing traps due to fault reactivation or tilting.
\end{abstract}

The term 'passive margin' describes a region of extended continental crust, located adjacent to a divergent plate boundary at the time of initiation of seafloor spreading, but now located in an intraplate setting, and thus considered to be tectonically 'passive'. However, as demonstrated in this volume, many passive margins are subject to ongoing intraplate deformation and there has been much debate about the drivers for such behaviour. Intraplate deformation may be generated by plate boundary forces that are transmitted into the plate interiors, with deformation localized in zones of intraplate weakness (e.g. Ziegler et al. 1998; Sandiford et al. 2004). Alternatively, there may be within-plate drivers for intraplate deformation such as tractions imparted from the mantle below deforming regions (e.g. Gurnis et al. 1998; Müller et al. 2000) or hotspot-related processes (e.g. Brodie \& White 1994). This debate has been particularly active with respect to the North Atlantic passive margin which has seen significant Cenozoic deformation and uplift. In this region, debate has centred on the relative importance of deformation associated with the Iceland mantle plume versus deformation associated with compressional stresses transmitted from plate boundaries (Mid Atlantic Ridge and Alpine collisional zone), and perhaps to a lesser extent, glacially-related processes (see summary in Doré et al. 2002). It is instructive to analyse the Neogene-to-Recent deformation of Australia's passive margins in the context of this debate on the drivers of intraplate deformation. 
Structural and geomorphological expressions of Neogene-to-Recent intraplate deformation have been recognized within parts of the Australian continent (Sandiford 2003b; Twidale \& Bourne 2004; Clark \& Bodorkos 2004; Célérier et al. 2005; Quigley et al. 2006, 2007). This neotectonic record affords an opportunity to investigate whether present-day intraplate stresses as determined from techniques such as earthquake focal mechanism solutions and borehole break-outs in well-bores (Hillis \& Reynolds 2000) are consistent with the longer-term geological record, and to assess whether both intraplate stresses and neotectonic deformation are consistent with a first-order control by plate boundary forces. The variation of present-day stress orientations and neotectonic structural trends across the Australian continent provides a more robust test of the consistency of inferred stresses and neotectonic structures than is possible in continental areas where there is little variation in present-day stress orientation.

In this paper, we summarize and compare present-day intraplate stresses, seismicity and neotectonic deformation in four regions of the Australian continent, focusing on its passive margins, in order to evaluate the extent to which neotectonic deformation can be accounted for in terms of the boundary forces acting on the plate. We argue that plate boundary forces exert the firstorder control on the present-day intraplate stress field and on the neotectonic, intraplate deformation of Australia and thus that plate boundary forces are effectively transmitted thousands of kilometres into the plate's interior where they are responsible for intraplate deformation. We also discuss the implications for the controls on intraplate deformation of the Australian continent and for hydrocarbon occurrence.

\section{Intraplate stress field of Australia and plate boundary forces}

The Australian continent is situated within the interior of the composite Indo-Australian Plate (Figs 1 \& 2). Hillis \& Reynolds (2003) described present-day maximum horizontal stress orientations within the Australian continent using earthquake focal mechanism solutions ( $29 \%$ of the data), borehole break-outs and drilling-induced tensile fractures in hydrocarbon exploration wells $(44 \%$ and $7 \%$ of the data respectively) and hydraulic

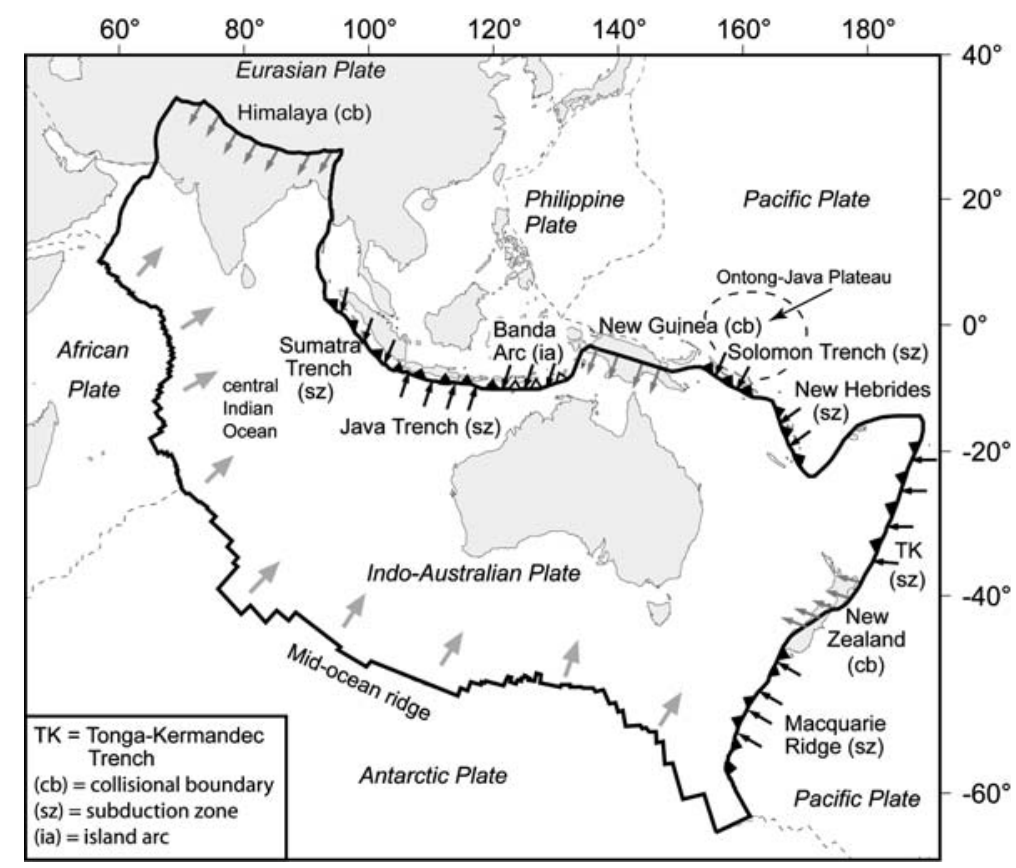

Fig. 1. Indo-Australian Plate showing the plate boundaries and forces discussed in the text. Large grey arrows indicate the mid-ocean ridge push force, small grey arrows indicate resisting continent-continent collisional forces, and small black arrows indicate slab pull forces. Solid triangles indicate the direction of subduction and open triangles delineate the Banda Arc. Modified after Reynolds et al. (2003). 


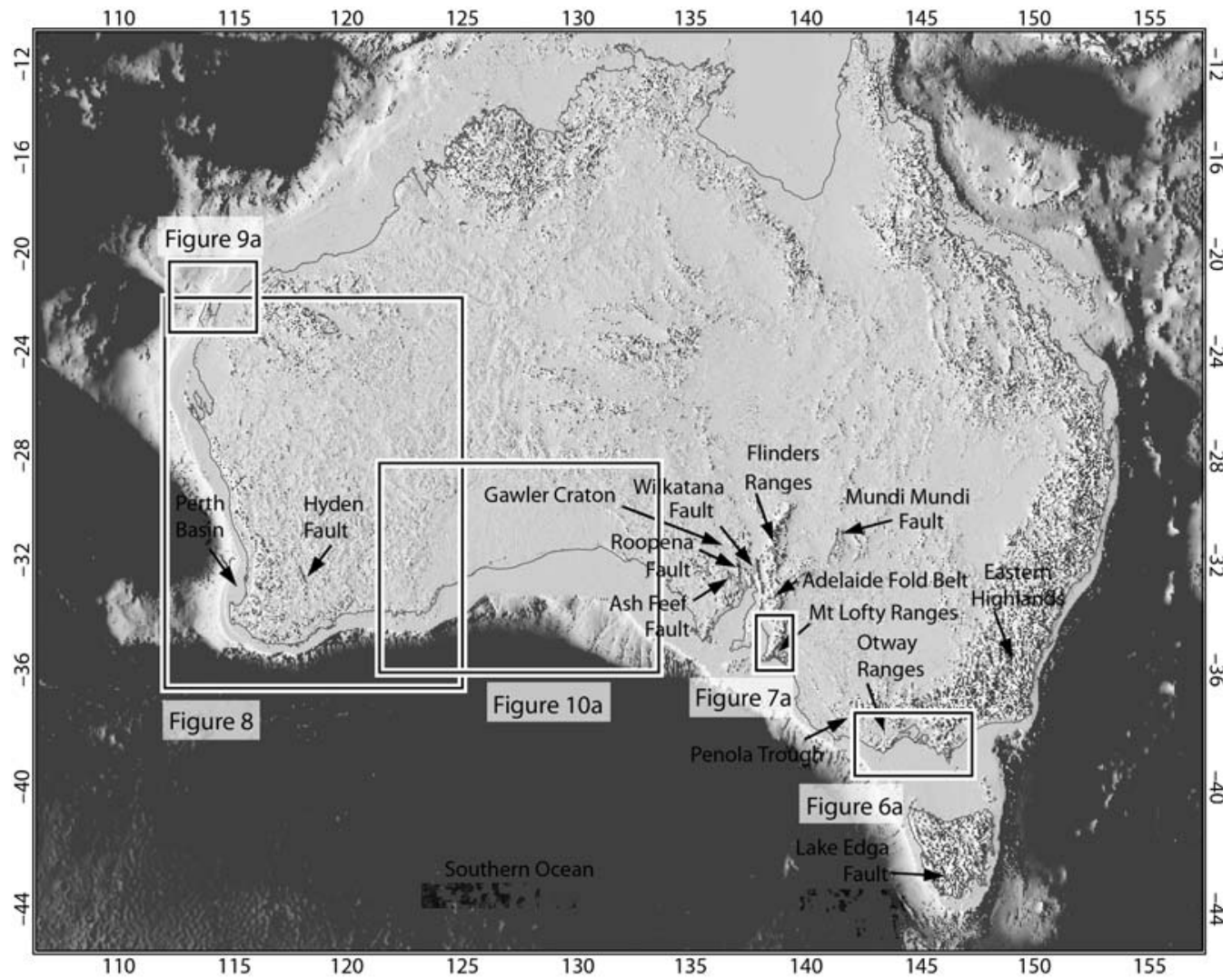

Fig. 2. Digital elevation map of Australia showing locations of figures and sites discussed in the text.

fracture tests, largely undertaken for coal mining purposes ( $18 \%$ of the data). Some 549 stress orientation measurements are available for the Australian continent, 331 of which are considered to be reliable (Fig. 3a). These data were derived independently of the information related to Neogene-to-Recent structures within the Australian continent presented herein. The stress data contain no orientations based on neotectonic structures, although elsewhere this is a recognized source of such information (Zoback 1992). The independence of these datasets is, of course, significant given that we compare present-day stress orientations and neotectonic deformation. The orientation of present-day maximum horizontal stress inferred from in-situ stress data is consistent within given regions of the Australian continent (e.g. individual sedimentary basins) but varies from region-toregion throughout the continent (Fig. 3). Present-day maximum horizontal stress is oriented east-west in western Australia. The east-west orientation rotates to NE-SW moving eastwards along the northern Australian margin and in central Australia. The east-west orientation rotates to NW-SE moving eastwards along the southern Australian margin. Regional stress orientations in the Australian continent are not affected to a first-order by tectonic province, crustal thickness, heat flow, regional structural trends, geological age or by the depth at which orientations are sampled. Numerous workers (e.g. Coblentz et al. 1998; Reynolds et al. 2002; Sandiford et al. 2004) have thus sought an explanation for present-day intraplate stress trajectories in terms of plate boundary forces generated at the margins of the Indo-Australian Plate (Fig. 1).

The NE boundary of the Indo-Australian Plate exhibits a uniquely complex and laterally varying set of convergent tectonic styles. Continental collision is occurring along the Himalayan, New Guinea and New Zealand segments of the plate boundary (Fig. 1). Oceanic parts of the Indo-Australian Plate are being subducted at the Sumatra-Java and Solomon-New Hebrides Trenches, and the Pacific Plate is being subducted under the Indo-Australian Plate at the 


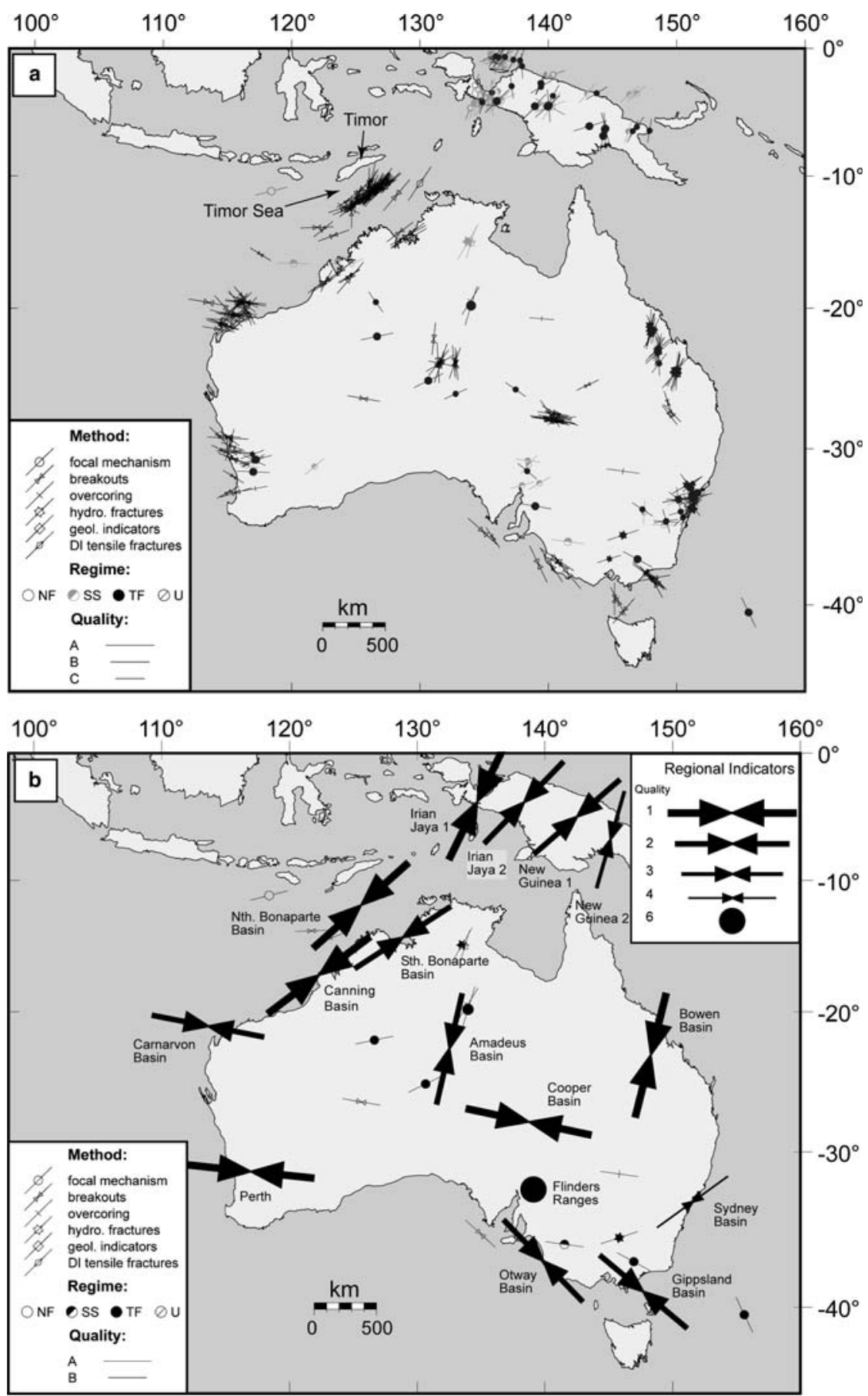

Fig. 3. Australian Stress Map. (a) Orientations of the bars indicate orientations of present-day maximum horizontal stress using the techniques indicated in the key. The length of the bar represents the quality (reliability) of the inferred stress orientation. Only reliable, A-C quality data are included. D and E quality data are omitted (from Hillis \& Reynolds 2003).(b) Mean stress orientations within Australian stress provinces. The size of the arrow indicates the consistency of stress orientations within the province. Isolated A- and B-quality data that do not lie within the defined stress provinces are also shown (from Hillis \& Reynolds 2003). 
Tonga-Kermadec Trench. The rotation of stress orientation from east-west to NE-SW along the northern margin of Australia results in stress trajectories aligning orthogonal to the collisional New Guinea segment of the NE convergent boundary of the Indo-Australian plate. The rotation of stress orientation from east-west to NW-SE along the southern margin of Australia results in stress trajectories aligning orthogonal to the collisional New Zealand segment of the plate boundary. Qualitatively this suggests that these collisional plate boundary segments exert an important control on intraplate stresses.

Coblentz et al. (1998) and Reynolds et al. (2002) undertook two-dimensional, elastic finite element analysis of the intraplate stress field of the Indo-Australian Plate based on the forces applied to the plate boundaries (Fig. 4). In their first model, Coblentz et al. (1998) ignored the complexity of the NE convergent boundary of the Indo-Australian Plate and balanced the ridge push force associated with the SW plate boundary equally along the length of the convergent $\mathrm{NE}$ boundary. This model predicts maximum horizontal stresses that are consistent throughout the plate and parallel to the direction of absolute plate motion (i.e. NNE-oriented). This simple model is broadly similar to successful models of the intraplate stress field of continental areas such as western Europe (Gölke \& Coblentz 1996) and South America (Coblentz \& Richardson 1996), where the present-day maximum horizontal stress orientation is indeed consistent and parallel to the direction of absolute plate motion. However, it does not match stress observations within the Australian continent.

In subsequent models, Coblentz et al. (1998) balanced (focused) the ridge push force associated with the SW boundary of the Indo-Australian Plate against the collisional segments of the NE boundary (i.e. Himalayas, New Guinea and New Zealand) and successfully reproduced the broad, continental-scale rotations in maximum horizontal stress orientation across the Australian continent described above. Reynolds et al. (2003) statistically compared the intraplate stresses predicted by plate boundary force models of the Indo-Australian Plate (permitting different forces along the NE boundary segments) with the observed stress data. The best-fitting model provides an excellent fit to the observed stress data (Fig. 4). This indicates that despite the fact that the present-day maximum horizontal stress orientation within the Australian continent is not parallel to the direction of absolute plate motion, it is consistent with a first-order control by plate boundary forces, provided the complexity of the NE convergent boundary of the Indo-Australian Plate is taken into account.

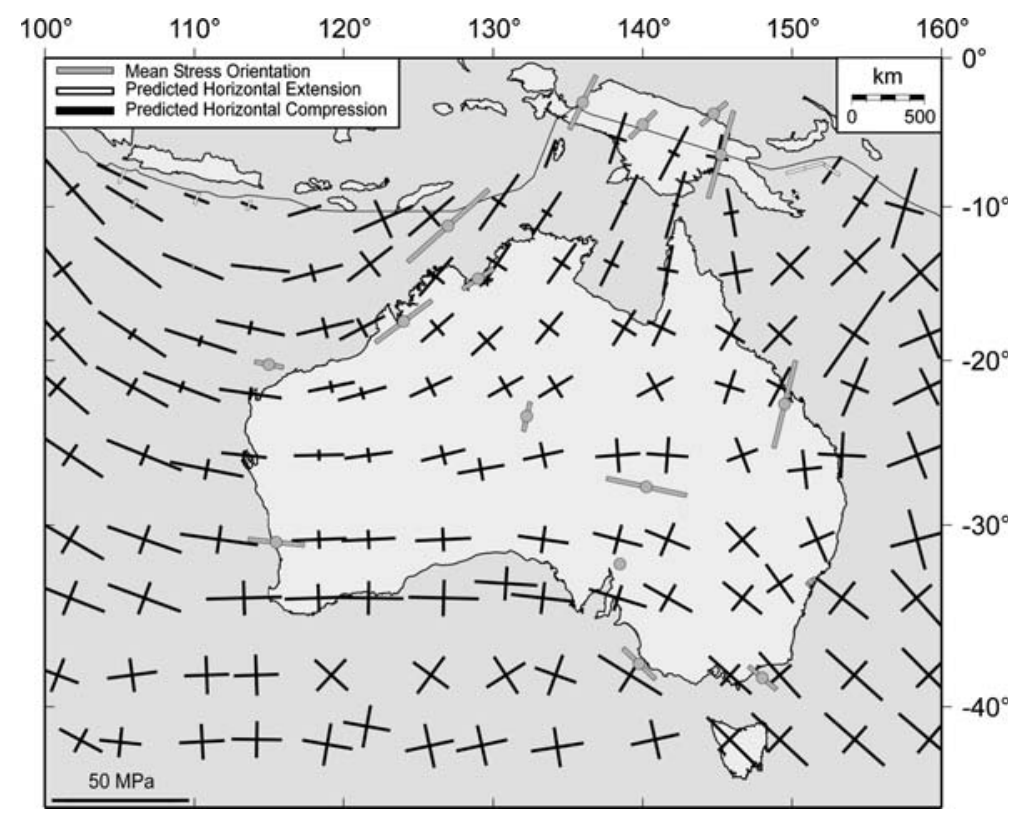

Fig. 4. Plate boundary force stress model that provides the best fit to observed stress data for the Australian continent (from Reynolds et al. 2003). 


\section{Seismicity and present-day stress of Australia}

Australia shows a relatively high level of seismicity for a continent remote from plate boundaries (Fig. 5). In terms of individual earthquakes, large (M c. 6.8), surface rupturing earthquakes have occurred at Meckering (1968) and Tennant Creek (1988). In 1989, the M5.6 Newcastle earthquake resulted in 13 fatalities. In a comparison of seismic activity rates in stable continental regions (SCRs), Johnston (1994) showed that Australia was amongst the most active of SCRs, together with China and North America. Estimated activity rates in Australia are significantly higher than northern Europe, cratonic South America and Africa. India is the most seismically active SCR (Johnson 1994). Calculations of seismic strain rates from activity rates in SCRs are highly uncertain given the incompleteness of the historical databases from which they are derived. They do, however, provide one view of the 'instantaneous' intraplate deformation field and its variability. On the basis of the activity rates, Johnston (1994) deduced a bulk seismogenic strain rate for the Australian continent of $c .10^{-17} \mathrm{~s}^{-1}$, about four times faster than northern Europe and about four times slower than India. Sandiford et al. (2004) and Célérier et al. (2005) used a similar approach to derive seismogenic strain rates in the most active parts of south-central Australia which are of the order $10^{-16} \mathrm{~s}^{-1}$; a rate that on the geological time scale should produce significant deformation.

Earthquake epicentral locations define four distinct zones of enhanced seismicity across the Australian continent (Fig. 5). (1) The SE Seismic Zone, extending in a coastal belt from central New South Wales through the eastern half of Victoria into Tasmania, including the passive margin bordering the Tasman Sea and the most SE part of the passive margin bordering the Southern Ocean. (2) The Flinders Seismic Zone,

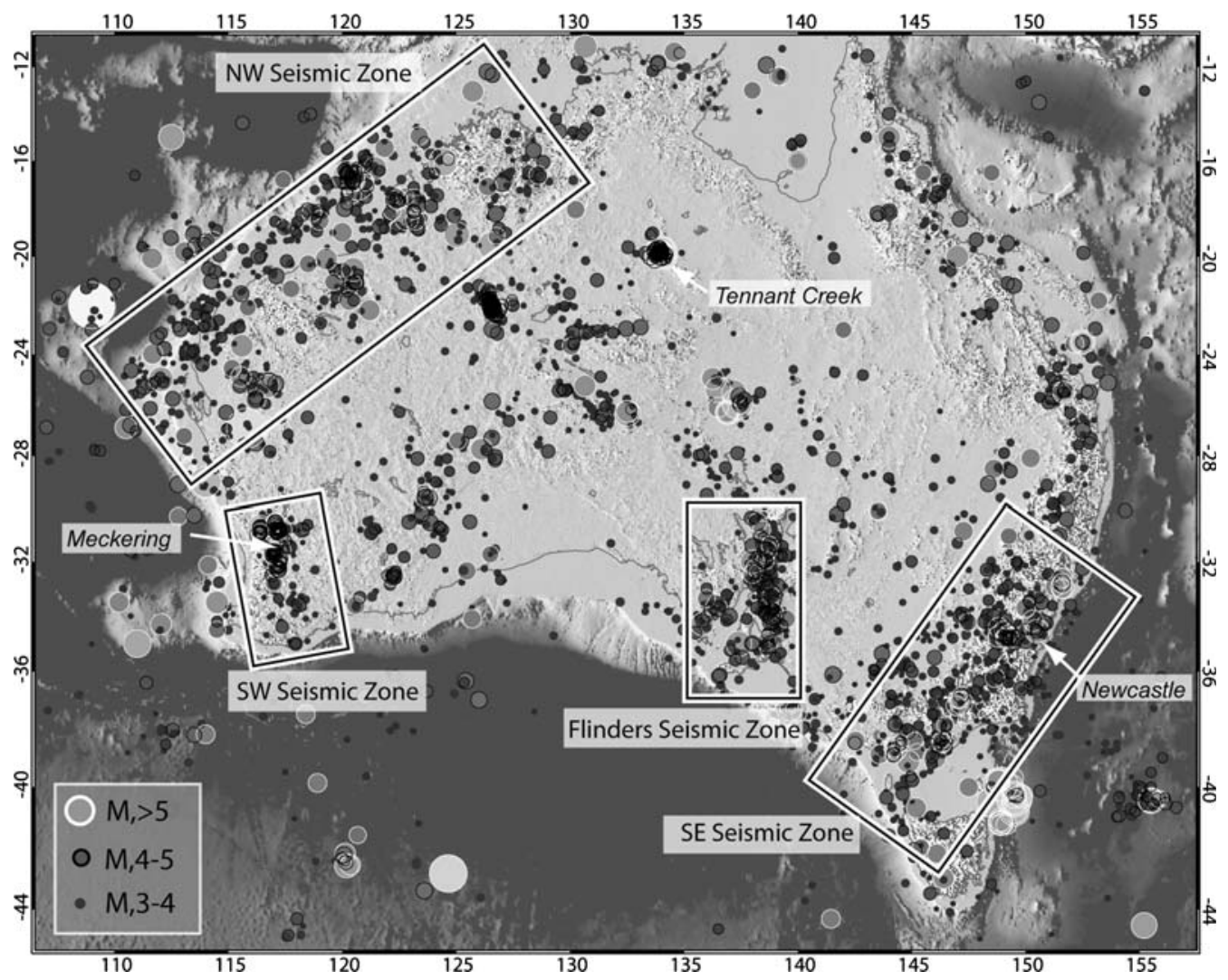

Fig. 5. Distribution of $M>3$ earthquakes and designated seismic zones in Australia. Earthquake epicentre data courtesy of Geoscience Australia. Magnitude measures are based on local magnitudes (ML) for M $<5.5$ and surface magnitude $(\mathrm{Ms})$ for $\mathrm{M}>5.5$. The locations of notable Australian earthquakes including the $1968 \mathrm{Ms} 6.8$ Meckering earthquake; 1988 Ms 6.8 Tennant Creek earthquake, and 1989 Ms 5.6 Newcastle earthquake are shown. 
extending from the Flinders and Mount Lofty Ranges to the eastern Gawler Craton. (3) The SW Seismic Zone of SW Western Australia which extends to the southern part of Western Australian Indian Ocean passive margin. (4) The NW Seismic Zone located mainly on the NW Shelf, the passive margin bordering the Indian Ocean and Timor Sea.

Present-day maximum horizontal stress is oriented NW-SE throughout the SE Australian passive margin, albeit rotating slightly from $125^{\circ} \mathrm{N}$ in the South Australian Otway Basin to $135^{\circ} \mathrm{N}$ in the Victorian Otway Basin to $140^{\circ} \mathrm{N}$ in the Gippsland Basin (Fig. 6; Nelson et al. 2006). Allen et al. (2005) calculated a composite fault plane solution using four eastern Victorian earthquakes (immediately north of the Gippsland Basin) with the solution indicating a reverse fault mechanism with present-day maximum horizontal stress oriented $145^{\circ} \mathrm{N}$.

Earthquake focal mechanism solutions in the Flinders Seismic Zone indicate strike-slip and reverse mechanisms with a broadly east-west oriented present-day maximum horizontal stress orientation, but with some scatter in orientations (Fig. 7; Hillis \& Reynolds 2000, 2003). Clark \& Leonard (2003) inverted six earthquake focal mechanisms from the Flinders Ranges in a composite solution indicating that the maximum principal stress is sub-horizontal and oriented $082^{\circ} \mathrm{N}$.

Present-day maximum horizontal stress in the SW Seismic Zone is oriented east-west (Hillis \& Reynolds 2003; Fig. 8). Borehole break-outs in the Perth Basin (Fig. 2) indicate an east-west oriented present-day maximum horizontal stress (Fig. 8; Reynolds \& Hillis 2000). Shallow (3-10 $\mathrm{m}$ depth) overcoring-based stress measurements were undertaken near the epicentres of the 1968 Meckering and 1970 Calingiri earthquakes and both the overcoring measurements and the focal mechanism solutions for those events indicate east-west oriented present-day maximum horizontal stress (Denham et al. 1979). Clark \& Leonard (2003) inverted five earthquake focal mechanisms from the area, including the Meckering and Calingiri events, in a composite solution indicating that the maximum principal stress is horizontal and oriented $275^{\circ} \mathrm{N}$ with a pure compression focal mechanism.

There is extensive present-day stress data from the NW Seismic Zone in the form of borehole break-outs analysed in petroleum exploration wells in the Carnarvon Basin. Regional present-day maximum horizontal stress in the Carnarvon Basin is oriented c. $100^{\circ} \mathrm{N}$ (Hillis \& Reynolds 2003; Fig. 3). The original interpretation of break-outs in the Carnarvon Basin was based on caliper logs interpreted by Mildren (1997). The stress directions inferred from caliper logs in individual wells in the Carnarvon Basin show significant scatter, albeit with a mean direction of $c \cdot 101^{\circ} \mathrm{N}$ across the basin (standard deviation of $35^{\circ}$; Hillis \& Reynolds 2003). Image logs permit more confident interpretation of borehole break-outs than caliper logs, and permit the recognition of drilling-induced tensile fractures, which also indicate the direction of present-day horizontal stress. Recent, unpublished analysis of a large database of image logs indicates a consistent present-day maximum horizontal stress direction of $c .105^{\circ} \mathrm{N}$ across the Carnarvon Basin. Present-day maximum horizontal stress orientation in the Timor Sea (Fig. 3) is well constrained from analysis of borehole break-outs and drilling-induced tensile fractures on caliper and image logs from the area (Hillis \& Reynolds 2003). The mean present-day maximum horizontal stress direction in the area is $047^{\circ} \mathrm{N}$.

\section{Neotectonics of Australia}

Australia is often considered to be a tectonically stable continental region where ancient land surfaces predominate (Twidale \& Bourne 1975; Ollier 1978). This is true for much of the continent, but, as discussed above, Neogene-to-Recent tectonic activity is documented in many areas of Australia. A large number of prehistoric fault scarps have been identified onshore in Australia, testifying to a rich record of ongoing earthquake activity (Clark \& McCue 2003 and discussed further below). Several important conclusions and implications have been drawn from the studies of these features. Importantly, all documented onshore Quaternary faults involve either purely dip-slip or oblique-slip reverse movement. No Quaternary strike-slip or normal faults have been found. Fault kinematic data derived from fault plane and slickenline orientations from the Flinders Seismic Zone indicate a roughly east-west oriented palaeomaximum horizontal stress orientation, consistent with the orientation derived from historical seismicity (Sandiford 2003a; Quigley et al. 2006; Fig. 7).

Estimates of prehistoric SE Australian earthquake magnitudes $(\mathrm{M})$, based on fault rupture lengths, single-event displacements and inferred ranges of hypocentral rupture depth, range from $\mathrm{M}=5.8$ to 7.2 (Clark \& McCue 2003; Quigley et al. 2006). These data are consistent with estimates for the largest recorded Australian earthquakes (Meeberiee, WA 1941, $\mathrm{M}=7.3$; Meckering, WA 1968, $M=6.8$; Tennant Creek, NT 1988; $\quad M=6.8$ ). Quaternary fault slip rates derived from cumulative displacements of Pliocene and Quaternary sediments range from 

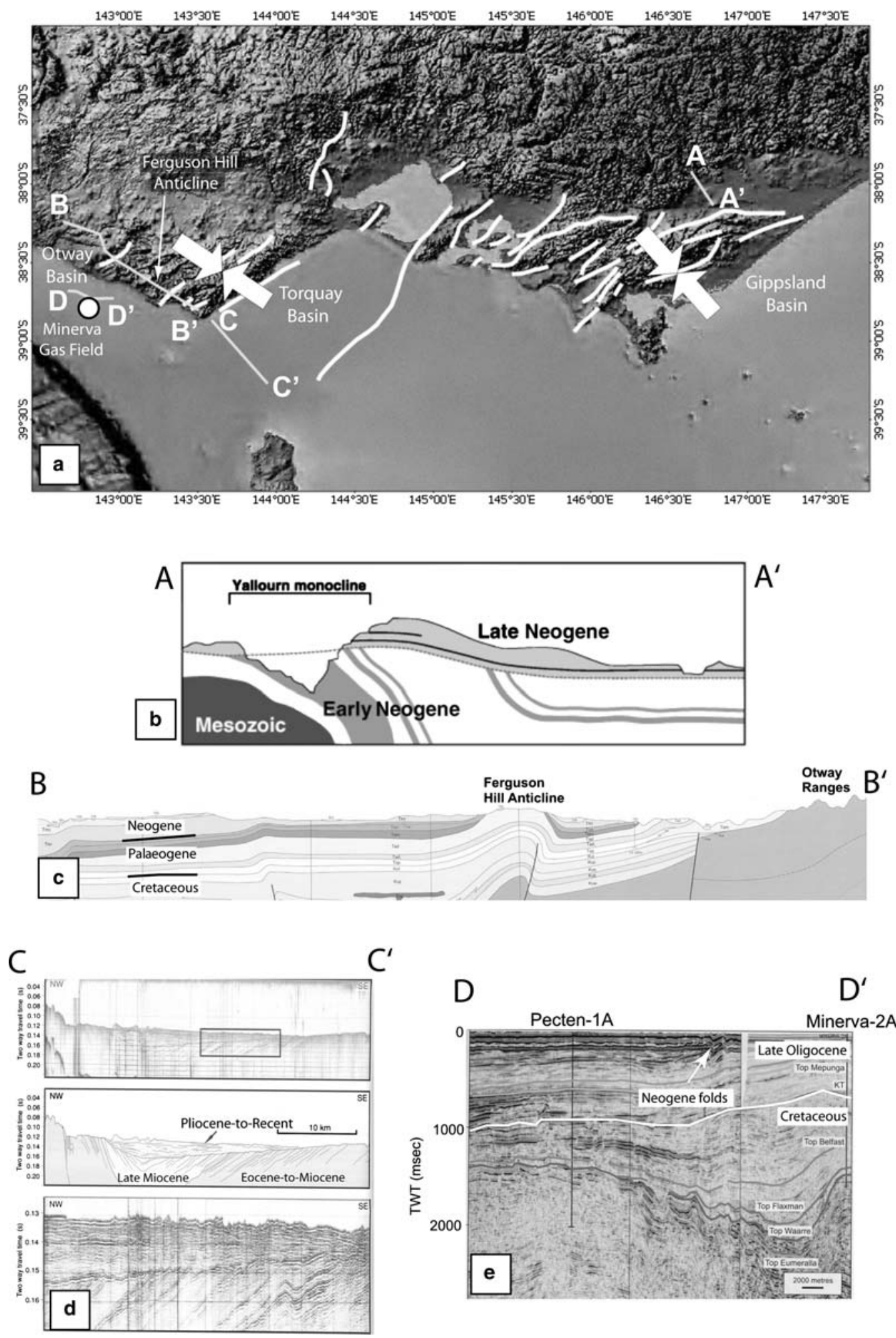
$20-150 \mathrm{mMa}^{-1}$, suggesting surprisingly high rates of deformation for an intraplate setting (Sandiford 2003a; Quigley et al. 2006). However, the longterm slip rates determined from individual fault exposures have proved more difficult to assess because of the tendency of intracontinental faulting to cluster in time and space (Crone et al. 1997, 2003). For example, faults in the Wilkatana area of the central Flinders Ranges appear to have incurred upwards of $15 \mathrm{~m}$ of cumulative slip since c. 67000 years ago (Quigley et al. 2006), much higher than any reasonable long-term average. Estimates of the recurrence interval of surface-rupturing earthquakes from Quaternary faults range from 1 per 22000 years to $\geq 1$ per 83000 years, although estimations of these rates are also limited by the sporadic nature of intracontinental faulting (Quigley et al. 2006).

Exposed Quaternary faults commonly occur along previously established geological boundaries and/or zones of crustal weakness (Fig. 2), including lithotectonic boundaries (e.g. Wilkatana and Roopena/Ash Reef Faults at the boundary between the Adelaide Fold Belt and Gawler Craton), ancient fault zones (e.g. Mundi Mundi Fault, Lake Edgar Fault) and range fronts (Flinders and Mt Lofty Ranges). Finally, it appears that earthquake activity may have resulted in upwards of several hundreds of metres of cumulative surface uplift in some parts of SE Australia, such as in the Flinders, Mt Lofty and Otway Ranges (Bourman \& Lindsay 1989; Tokarev et al. 1999; Sandiford 2003a; Quigley et al. 2006) and Eastern Highlands (Fig. 2), indicating a profound relationship between intraplate deformation and landscape evolution.

\section{Neogene deformation of Australia's passive margins}

In the following sections, we summarize evidence of Neogene-to-Recent tectonic activity in the SE passive margin (Otway, Torquay and Gippsland
Basin), the Flinders and Mount Lofty Ranges, onshore SW Western Australia, and the NW Australian passive margin (Carnarvon Basin and Timor Sea). These areas where Neogene-to-Recent tectonic activity can most easily be observed correspond with the areas of elevated historical seismic activity described above, suggesting that deformation is continuing to the present-day. We also compare Neogene-to-Recent structural trends to the present-day stress field.

\section{SE Australian passive margin: Otway, \\ Torquay and Gippsland Basins}

There is extensive evidence for Miocene-Recent deformation on Australia's SE passive margin. Figure 6a shows the major Neogene faults of the area as interpreted by Dickinson et al. (2002). The Minerva Gas Field of the offshore Otway Basin is located on a NE-trending inversion anticline which records a major period of Miocene-Recent compression (Schneider et al. 2004; Sharp \& Wood 2004; Fig. 6e). Similar, NE-trending Miocene-Recent anticlines occur onshore such as the Ferguson Hill anticline (Port Campbell Embayment 1:100 000 Geological Map Sheet; Fig. 6c). These structures lie just to the west of the Otway Ranges on which strandlines indicate c. $200 \mathrm{~m}$ of uplift since early-mid Pliocene (Sandiford 2003a, $b$; Sandiford et al. 2004). In the Torquay Basin, folding and faulting affects the entire section up to the upper Miocene and up to $400 \mathrm{~m}$ of Miocene section has been eroded from anticlinal crests (Fig. 6d). Deformation and erosion must postdate the upper Miocene because that section is conformable and uniformly affected by deformation (Dickinson et al. 2002). A very pronounced Miocene-Pliocene angular unconformity is apparent in the basin (Fig. 6d). On shallow seismic records near the shoreline, faulting is evident within the Pliocene, indicating that deformation continued into the Pliocene (Dickinson et al. 2002). The Miocene-Recent structures of the Torquay Basin broadly strike NE-SW but

Fig. 6. Compilation of present-day stress and neotectonic data for the SE Australian margin. (a) Map shows neotectonic fault scarps interpreted by Dickinson et al. (2002) superimposed on digital elevation data. Block arrows indicate mean regional present-day maximum horizontal stress orientations from Hillis \& Reynolds (2003). Map also shows locations of cross-sections in (b)-(e). (b) Cross-section of the Yallourn monocline, showing strong deformation of early Neogene sediments and mild deformation of late Neogene sediments (from Barton 1981). (c) Cross-section showing deformation of Neogene sediments at Ferguson Hill (Port Campbell Embayment 1: 100000 Geological Map Sheet). (d) Seismic data and interpretation from the Torquay Basin, showing strong deformation of late Miocene strata and mild deformation and folding of unconformably overlying Pliocene-Recent strata (from Dickinson et al. 2001). (e) Seismic profile through the Minerva Gas Field in the Otway Basin. Deformation of late Oligocene strata indicates Miocene or younger folding. Drilling-induced tensile fractures in the Minerva-1 and Minerva-2A wells indicate NW-SE-oriented present-day maximum horizontal stress (Nelson et al. 2006), orthogonal to and consistent with the orientation of the Miocene-Recent anticlines observed in the profile (Sharp \& Wood 2004). 

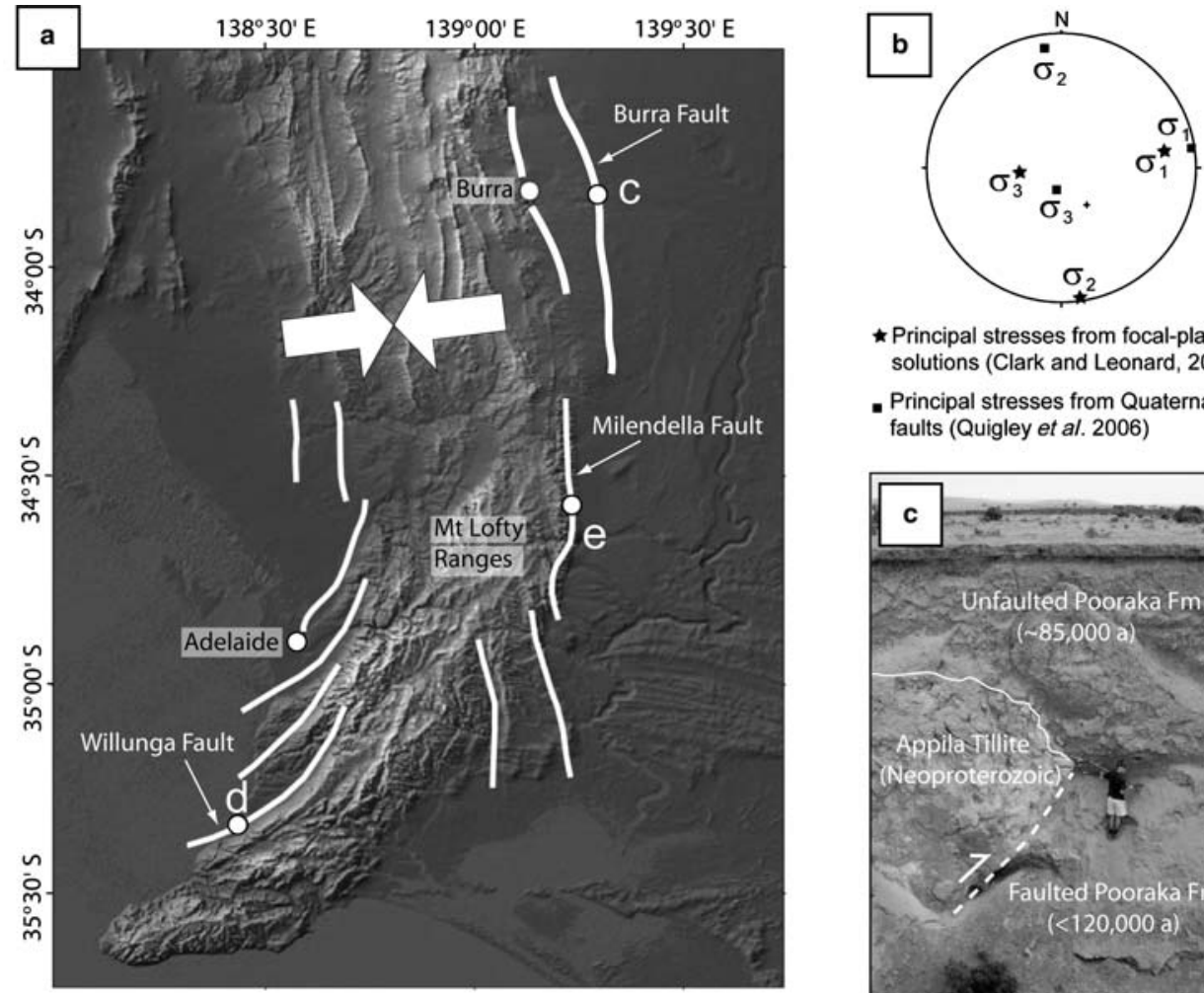

$\star$ Principal stresses from focal-plane solutions (Clark and Leonard, 2003)

- Principal stresses from Quaternary faults (Quigley et al. 2006)
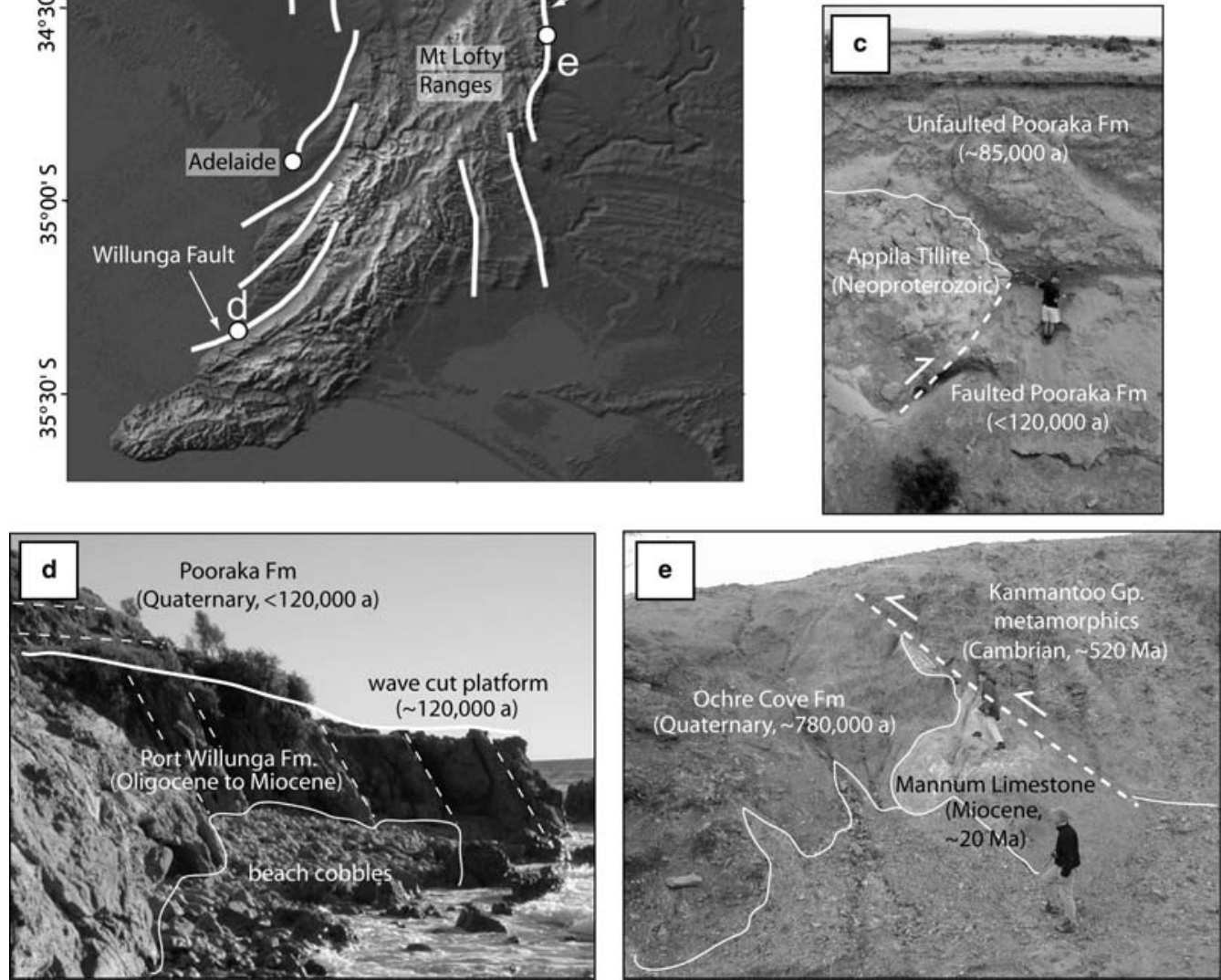

Fig. 7. Compilation of present-day stress and neotectonic data for the southern Flinders and Mount Lofty Ranges. (a) Map shows neotectonic fault scarps interpreted by Sandiford (2003b) and Quigley et al. (2006) superimposed on digital elevation data. Block arrows denote mean regional present-day maximum horizontal stress orientation from Hillis \& Reynolds (2003). Map also shows locations of field photos/sketches in (c)-(e). (b) Comparison of principal compressive stresses derived from eight focal-plane solutions of Flinders Ranges earthquakes for the interval 19771991 (Clark \& Leonard 2003) and from field measurements of the Wilkatana, Burra, and Mundi Mundi Faults (Quigley et al. 2006). Stress magnitudes are defined such that compressive stresses are positive and $\sigma_{1}>\sigma_{2}>\sigma_{3}$. Note similarity in stresses derived from historical and neotectonic datasets (from Quigley et al. 2006). (c) Burra Fault locality, showing a reverse fault that displaces Neoproterozoic basement rock over late Quaternary sediment (Pooraka Formation). View looking north (from Quigley et al. 2006). (d) Willunga Fault locality, showing a c.120 ka BP wave-cut platform in the uplifted hanging wall of the Willunga Fault situated roughly 4-5 $\mathrm{m}$ above present sea level, indicating post $c .120 \mathrm{ka}$ uplift. Steeply dipping Oligo-Miocene strata further testify to Neogene deformation. View looking south (from Sandiford 2003b). (e) Milendella Fault locality, showing metamorphic basement rocks thrust over Quaternary sedimentary rocks. View looking south (from Sandiford 2003b). 


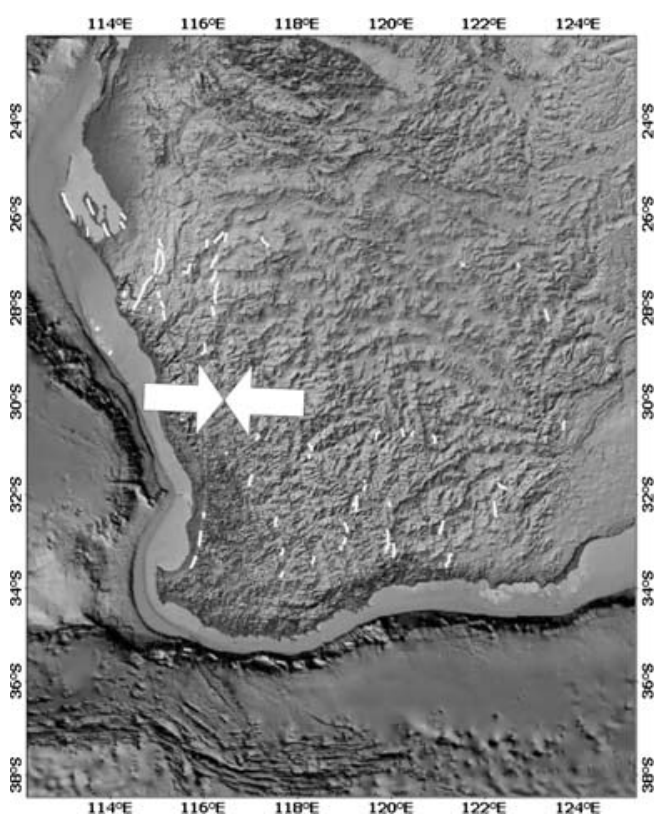

Fig. 8. Compilation of present-day stress and neotectonic data for SW Western Australia. Map shows neotectonic fault scarps interpreted by Clark (2005) superimposed on digital elevation data. Block arrows indicate mean regional present-day maximum horizontal stress orientation from Hillis \& Reynolds (2003).

have not been mapped in detail nor are present-day stress orientations available for the Torquay Basin.

Miocene-Recent compression is also witnessed in the coalfields of the onshore Gippsland Basin, for example in the NE-SW-striking Yallourn monocline where a major angular unconformity separates Pliocene from Miocene (Barton 1981; Fig. 6b). Regionally, throughout the onshore Gippsland Basin, Neogene-to-Recent monoclines and reverse faults strike NE-SW to east-west and river channels cut across present-day uplifted structures, suggesting that uplift continued into the middle Pleistocene (Holdgate et al. 2003).

Offshore in the Gippsland Basin, where the predominant inherited structural trend is ESE, only east-west to NE-SW striking faults have been reactivated in compression (Power et al. 2003). The neotectonic structures of the Otway and Gippsland Basins are consistent with the previously described reverse faulting present-day stress regime with maximum horizontal stress oriented NW-SE.

\section{Flinders and Mount Lofty ranges}

The Quaternary tectonic record of the Flinders and Mount Lofty ranges is dominated by north- to NE-striking, range-bounding reverse faults recording approximately east-west shortening (Sandiford 2003b; Sandiford et al. 2004; Célérier et al. 2005; Quigley et al. 2006). Figure 7 shows neotectonic scarps of the Mount Lofty Ranges as interpreted by Sandiford (2003b) and Quigley et al. (2006). The associated faults are largely buried beneath alluvial fans, but are occasionally exposed in coastal and river sections. At Sellicks Beach canyons provide sections from the hanging wall to the footwall of the Willunga Fault (Fig. 7d). Reverse fault motion is indicated by steep east-dipping fault traces in the hanging-wall sequence close to the main fault trace. Tilting of the Oligocene to lower Miocene section indicates post-early Miocene deformation (Sandiford 2003b). The Milendella Fault is part of the eastern range-bounding fault system of the Mount Lofty Ranges, strikes north-south and comprises a west-dipping thrust which juxtaposes Cambrian metamorphic rocks in the hanging wall against Miocene and Quaternary rocks in the footwall (Fig. 7e). Further north in the Flinders Ranges, the Burra, Wilkatana and Paralana Faults all thrust Proterozoic basement over Quaternary deposits (Célérier et al. 2005; Quigley et al. 2006; Fig. 7c). Field measurements of fault orientations and slickenlines on the Wilkatana, Burra and Mundi Mundi Faults yield a maximum principal palaeostress orientation similar to inferred present-day stresses derived from historical earthquake focal mechanisms (Quigley et al. 2006; Fig. 7b).

\section{SW Western Australia}

The evidence of neotectonic activity in onshore SW Western Australia is less dramatic than in the Flinders and Mount Lofty ranges of South Australia. Topography is more subdued and we are not aware of sections through neotectonically-active faults, although trenching of the Hyden Fault scarp (Fig. 2) has revealed evidence of repeated Quaternary displacement (Clark et al. 2008). However, recent analysis of digital elevation data has revealed numerous faults scarps (Clark 2005; Fig. 8). The fault scarps strike north-south across the entire region. Most scarps where a displacement sense could be determined from the digital elevation data suggest reverse displacement on the underlying fault (Clark 2005). Nineteen of the features have been verified by ground-truthing and range in apparent age from less than a thousand years to many tens of thousands of years (Clark 2005). The north-south striking reverse fault scarps of SW Western Australia are consistent with the previously described reverse faulting present-day stress regime with maximum horizontal stress oriented east-west as inferred from historical earthquake focal mechanisms, overcoring and borehole breakouts. 


\section{NW Australian passive margin:}

Carnarvon Basin and Timor Sea

The North West Cape (Fig. 9) is a peninsula formed by the Cape Range anticline, the NNE-strike of which is parallel to the coastline of the peninsula (the onshore anticlinal trace shown on Fig. 9a). The Rough Range (Fig. 9b) and Giralia anticlines are parallel to the Cape Range anticline and are also both apparent on the digital elevation data for
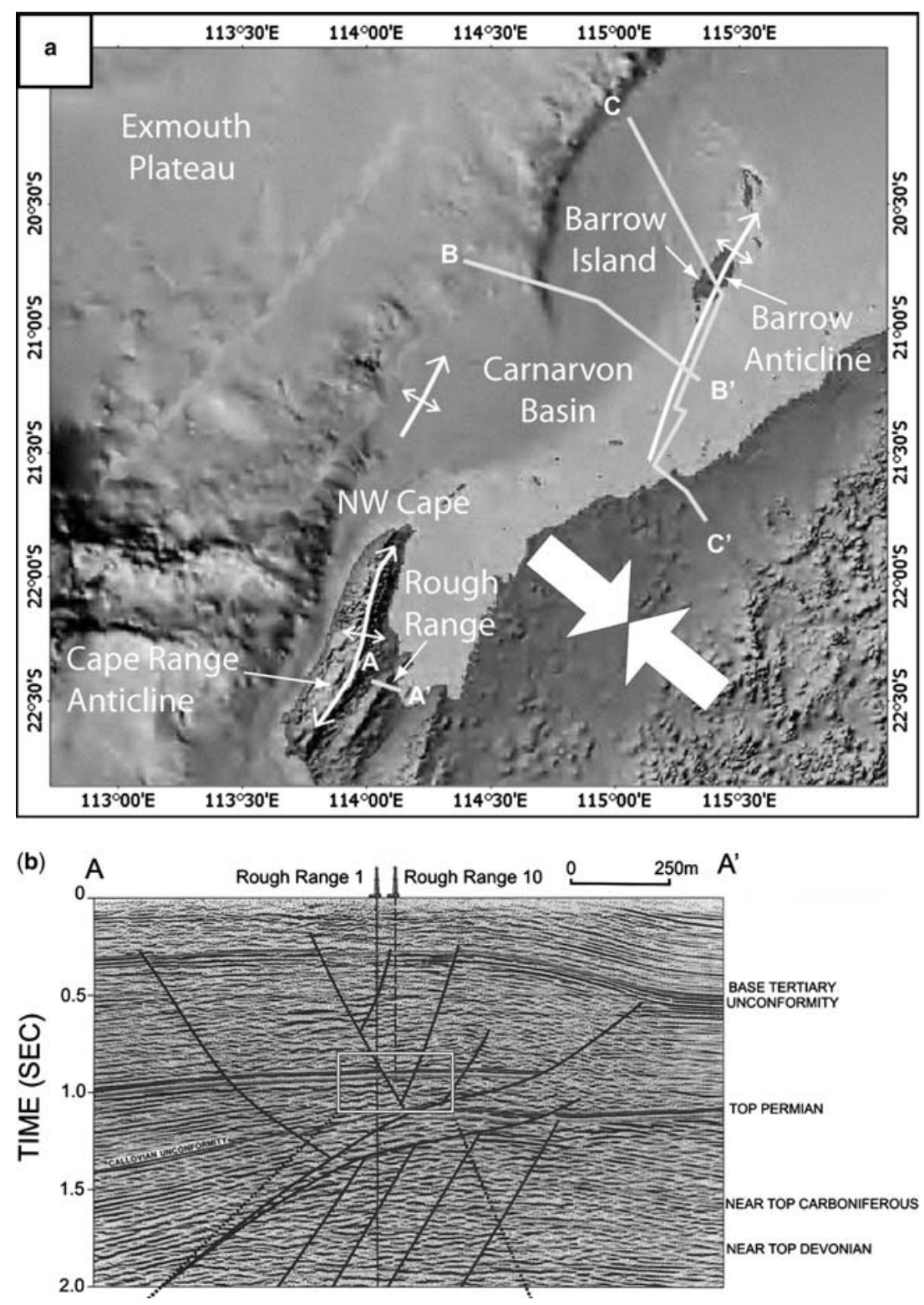

Fig. 9. Compilation of present-day stress and neotectonic data for the NW Australian margin. (a) Map shows anticlines with major growth during the Miocene as interpreted by Barber (1988) superimposed on digital elevation data. Block arrows indicate mean regional present-day maximum horizontal stress orientations from Hillis \& Reynolds (2003). Fold axes strike orthogonally to the present-day maximum horizontal stress orientation. Map also shows locations of cross-sections in (b)-(d). (b) Seismic section through the Rough Range anticline showing deformation of base Tertiary and younger (undated) reflectors (from Malcolm et al. 1991). 
(c)
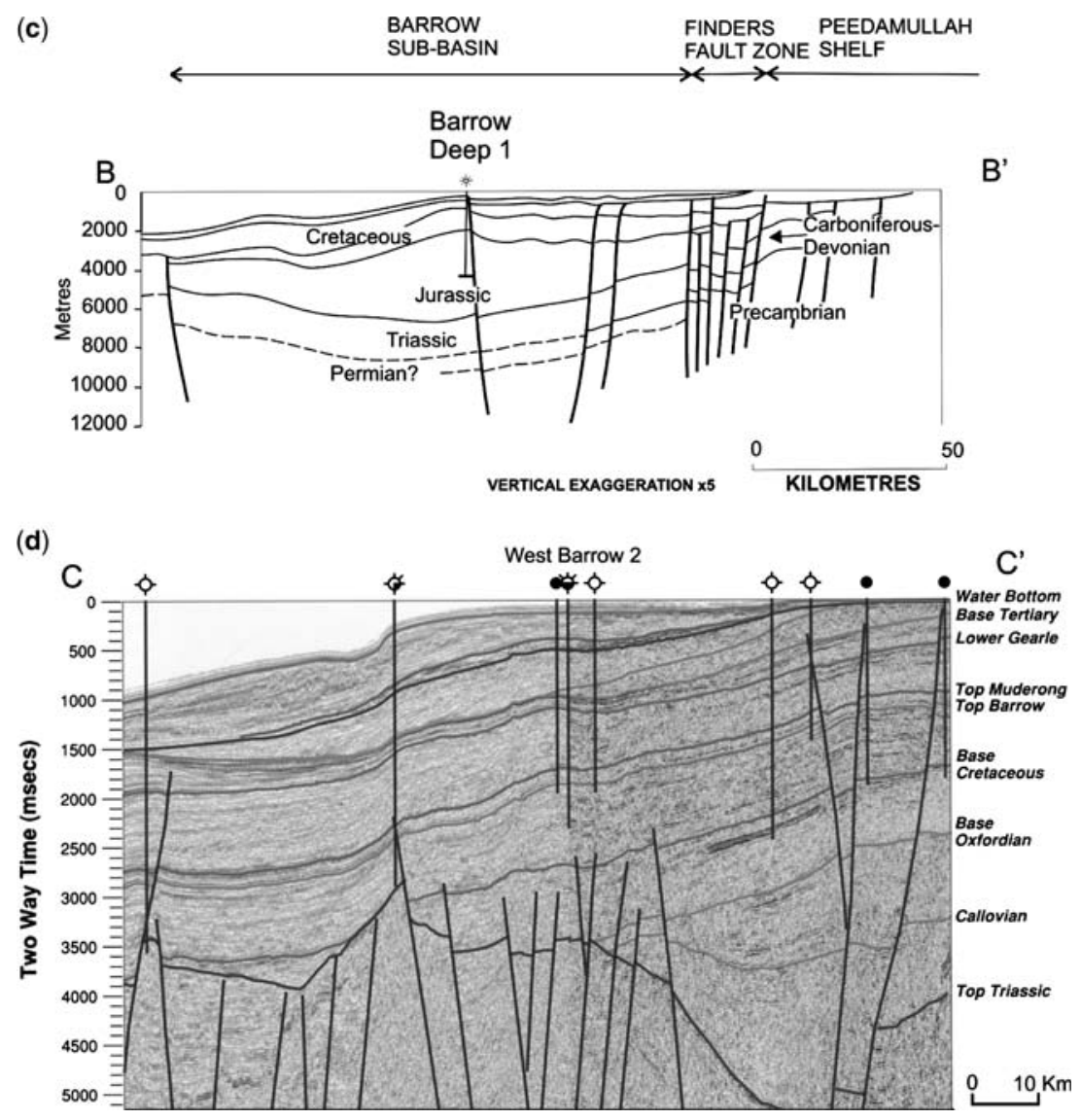

Fig. 9. (Continued) (c) Regional cross-section through Barrow Island showing that the Barrow Deep was a Jurassic depocentre subsequently inverted and uplifted in Cenozoic times (from Williams \& Poynton 1985). (d) Seismic section through Barrow Island showing the inverted Jurassic depocentre with the base Tertiary almost exhumed to the surface above the depocentre (from Hearty et al. 2002).

the area. Several islands in the Carnarvon Basin also overlie anticlines, the largest of these being Barrow Island which is located along the crest of the Barrow anticline where broad inversion is clear (Fig. 9c, d ). The Barrow Island inverted anticline follows the same NNE-trend as the anticlines of North West Cape. Figure 9 shows the Cape Range, Barrow and a third NNE-trending anticlinal structure as mapped by Barber (1988) with major growth dated as 'Miocene'. The anticlines are generally asymmetric because they have developed as fault propagation folds above reversely reactivated normal faults (Hocking 1988).

Although reverse reactivation of older normal faults, and the associated growth of fault propagation anticlines, is generally dated as Miocene in the Carnarvon Basin (e.g. Barber 1988; Hearty et al. 2002), little detailed dating on the age of their growth has been published. Emerged Pleistocene marine terraces on the Cape Range anticline indicate that deformation continued after the Miocene (Van De Graff et al. 1976). Indeed, the deeper water Exmouth Plateau was significantly folded and uplifted during this 'Miocene' event (Barber 1988) and doming of the present-day seabed suggests that deformation continues to the present-day. There is also evidence from onlap and facies variation in the Palaeogene and Cretaceous that indicates that some anticlines have been present since those times (Hocking 1988). That deformation continues to the present-day in the Pilbara Craton adjacent to the Carnarvon Basin is demonstrated by neotectonic fracture systems in granite pavements that cut aboriginal petroglyphs (Clark \& Bodorkos 2004). The ESE-oriented maximum horizontal palaeostress 
direction implied by the NNE-trending anticlines and inverted normal faults of the Carnarvon Basin is consistent with the previously described ESE orientation of the present-day maximum horizontal stress inferred from borehole break-outs and drilling-induced tensile fractures in petroleum exploration wells in the region.

At the other end of the NW Australian passive margin, the Timor Sea region of the margin is in collision with the Indonesian Banda Island Arc (Fig. 1), with the former passive margin being deformed in this active collision zone. The island of Timor (Fig. 3) comprises material accreted from the Australian Plate and the $2000 \mathrm{~m}$ deep Timor Trench to the south of Timor is an underfilled foreland basin on the Australian side of the collision zone. The Timor Sea is underlain by Australian passive margin south of the Timor Trough. Neogene-to-Recent fault reactivation is common in the Timor Sea with many faults reaching the seabed. The style of neotectonic faulting is unlike that observed elsewhere in Australia and is dominated by steeply-dipping, NE-SW to ENEWSW-striking faults on which there is apparent Neogene-to-Recent normal displacement (Keep et al. 1998; Harrowfield \& Keep 2005). There has been considerable debate regarding whether the regional system is one of normal faulting (e.g. Woods 1988) or whether the observed normal fault displacement occurs within an overall left-lateral wrench system (Nelson 1989; Shuster et al. 1998). The observed normal displacement on NE-SW-striking faults is consistent with the previously described NE-SW maximum horizontal stress orientation in the region if the vertical stress is the maximum principal stress (normal fault regime) and consistent with left-lateral motion on steeply dipping ENE-WSW striking faults if the maximum horizontal stress is the maximum principal stress (strike-slip fault regime).

\section{Controls on intraplate deformation}

Much of the contemporary debate concerning the sources of stress responsible for intraplate deformation is concerned with distinguishing stress transmitted from distant plate boundary interactions versus more local, within-plate sources, such as tractions imparted from the mantle at the base of deforming regions or hotspot-related processes. In most continental areas such as western Europe, South America and stable North America, the present-day maximum horizontal stress orientation is constant over thousands of kilometres and broadly parallels the direction of absolute plate velocity (Zoback 1992; Richardson 1992; Gölke \& Coblentz 1996). This observation has led many investigators to conclude that plate boundary forces are the principal control on the character of the intraplate stress field (Zoback 1992; Richardson 1992; Gölke \& Coblentz 1996). In contrast to these other plates, stress orientations in the Australian continent vary significantly and do not generally parallel the NNE direction of absolute plate motion (Figs $1 \& 2$ ). In the context of the neotectonic deformation of the Australian continent, it is not possible to preclude the role of relatively local, within-plate sources of stress in driving deformation in each of the widely separated regions we have described. However, as outlined above, the pattern of tectonic stress distribution derived from present-day stress data points to a long wavelength control that is now well understood in terms of a complex set of plate-boundary interactions (Coblentz et al. 1998; Reynolds et al. 2003). The relatively high levels of active seismicity further point to relatively high stress magnitudes and suggest that at geological time scales we would expect a permanent record in terms of neotectonic structures. There is indeed such a record in each of the four main seismogenic zones of Australia. Further, the orientations of the neotectonic structures accord with the pattern of present day stress and, where neotectonic structures are exposed or revealed in seismic sections, their style is consistent with present-day stress orientations. Together, these observations provide a strong case that the ongoing intraplate deformation field of the Australian continent is a primary response to distant plate boundary interactions. In support of this argument, the late Miocene onset of the Australian stress field in SE Australia, as indicated by structural and sedimentological studies, temporally coincides with significant changes in the nature of the Indo-Australian plate boundary zones (Fig. 1). These changes include: (1) the onset of transpression and mountain building in New Zealand relating to increased Pacific-Australian Plate convergence (Sutherland 1996; Walcott 1998); (2) the onset of compressional deformation and uplift along the Macquarie Ridge (Duncan \& Varne 1988; Massell et al. 2000); (3) the onset of transpressional deformation and uplift in New Guinea (Hill \& Hall 2003; Packham 1996); (4) collision between the Ontong Java Plateau and the Solomon Arc (Petterson et al. 1997; Wessel \& Kroenke 2000); (5) the onset of deformation in the central Indian Ocean (Cochran 1990; Krishna et al. 2001); and (6) major normal faulting in the Himalayan-Tibetan orogen (Harrison et al. 1992; Pan \& Kidd 1992).

The seismically and neotectonically active regions discussed above contrast markedly with the eastern part of the Great Australian Bight passive margin which borders the Southern Ocean (Figs $2 \& 10$ ). This area has amongst the lowest 

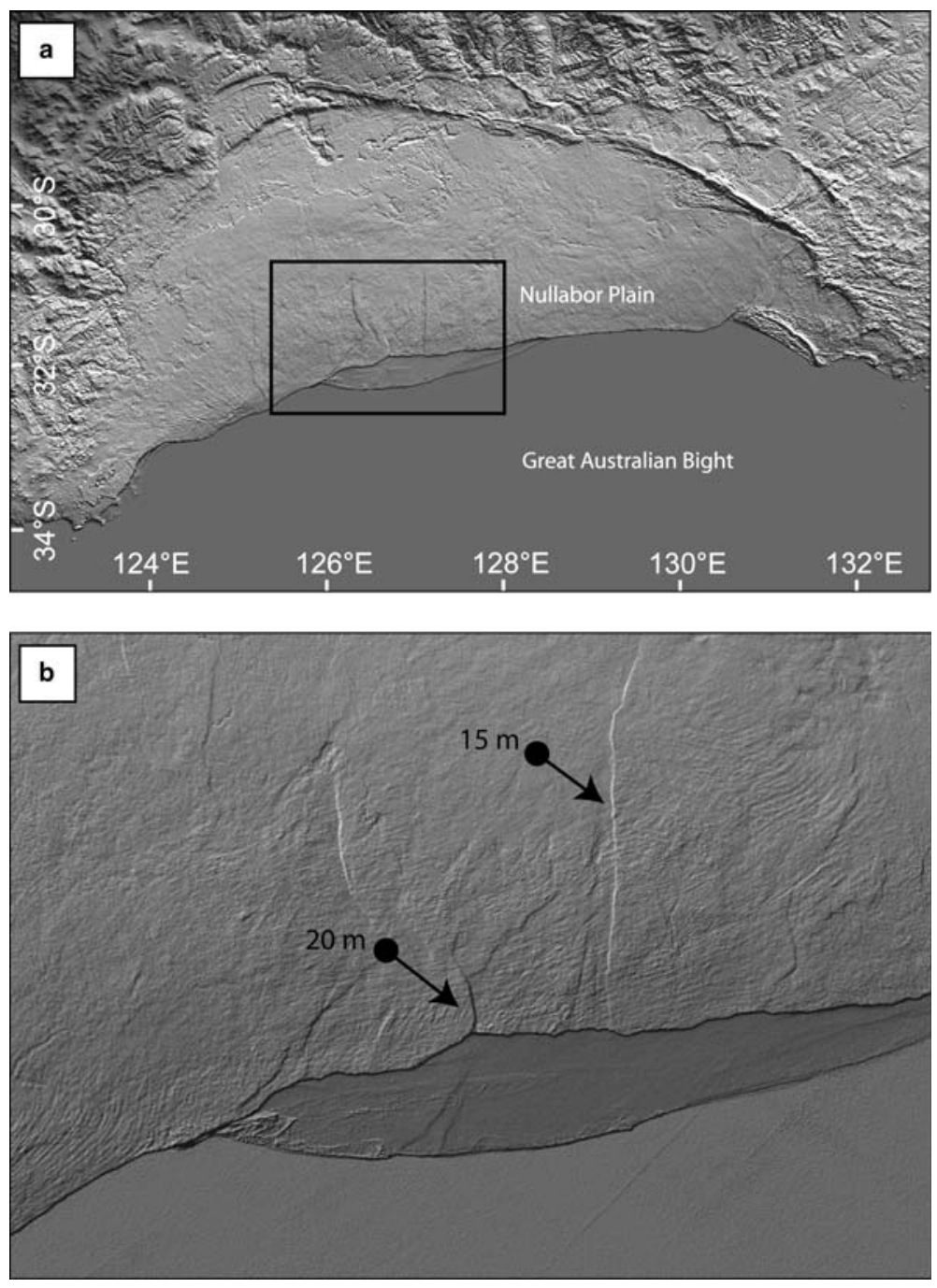

Fig. 10. Digital elevation data for southern central Australia and the Nullarbor Plain. The 15 Ma gently seaward-dipping depositional surface that forms the Nullarbor Plain is cut only by minor north-south trending faults with maximum displacements of $c .1 \mathrm{~m} \mathrm{Ma}^{-1}$. Arrows denote location of maximum fault scarp height measurements. The seismicity of the area is amongst the lowest in Australia (Fig. 5).

seismic activity rates of any part of the continent (Fig. 5). Further, the Nullarbor Plain (Figs $2 \&$ 10) provides extraordinary testimony to the longterm tectonic stability of this margin. This plain is defined by a vast marine limestone terrace more than $1000 \mathrm{~km}$ long and, at its widest, $300 \mathrm{~km}$ wide, which was exposed at $c .15 \mathrm{Ma}$ by gentle long wavelength uplift of the southwestern part of the Australian continent (e.g. De Broekert \& Sandiford 2005; Fig. 10). The almost total absence of subsequent fluvial processes on the plain has preserved virtually intact the $15 \mathrm{Ma}$ gently seaward-dipping depositional surface. Digital elevation data clearly reveal a number of small displacement, linear north-south trending faults across the western and central part of the plain (Fig. 10b), showing that the maximum fault displacements accumulated over $15 \mathrm{Ma}$ are everywhere less than a few tens of metres (or no more than about $1 \mathrm{~m}$ per million years). Much of the eastern part of the plain has been unaffected by faulting during this time. Although there are no present-day stress data for this area, the orientation of these small displacement faults is consistent with the east-west orientation of 
the present-day stress field inferred for the area from plate-boundary force modelling (Fig. 2).

The localization of seismicity and associated, longer-term neotectonic deformation into discrete regions within the Australian continent suggests that there are additional controls governing the spatial distribution of intraplate 'failure'. A high strength lithosphere is required to transfer tectonic stress over thousands of kilometres in intraplate regions. High differential stresses determined for the Gippsland and Cooper-Eromanga Basins (Nelson \& Hillis 2005; Reynolds et al. 2006) demonstrate the high strength of the upper crust in Australia (cf. Zoback et al. 1993). We suggest three possible broad causes of the localization of deformation into discrete regions:

- favourable orientation of passive margins with respect to present-day stresses;

- overpressuring of faults (pore pressure in excess of hydrostatic; Turner \& Williams 2004) so that faults are easier to reactivate, and;

- thermal weakening of the crust (associated with high concentrations of heat producing elements; e.g. McClaren et al. 2002) that allowed for focusing of deformation into anomalously weak zones.

In all the cases discussed here (except the Timor Sea), tectonic activity is confined to linear belts many hundreds of kilometres in length, aligned at a high angle to the present-day maximum horizontal stress (e.g. SE, Flinders and SW Seismic Zones). Deformation of the Australian 'passive' margins thus appears to be concentrated in areas where the margins are almost orthogonal to the present-day maximum horizontal stress (Fig. 3). Deformation in the Timor Sea reflects the interaction of plate boundary-derived forces and lithospheric flexure resulting from formation of the Timor Trough (Veevers \& Powell 1984; O’Brien et al. 1999). The inactive Great Australian Bight margin is aligned parallel to the prevailing maximum horizontal stress. The style of neotectonic deformation observed is thus likely to be influenced by the orientation of pre-existing zones of weakness in the margin (inherited faults) with respect to the presentday stress field. This is supported by neotectonic studies that suggested young faults locally reactivated ancient faults and/or shear zones (Crone et al. 2003; Quigley et al. 2006).

Overpressures have been demonstrated in the deeper parts of the Carnarvon (van Ruth et al. 2004) and Gippsland Basins (Nelson et al. 2006). Overpressure reduces the effective normal stress that resists shear failure. The extent of deformation on Australia's passive margins may at least in part reflect the development of overpressure in these basinal settings. However, active seismicity and neotectonic structures extend well onshore, into terranes exposing crystalline basement, beyond the likely limits of significant overpressuring. In the case of the Flinders Ranges, the high concentrations of heat-producing elements in the crust suggest a likely role for thermal weakening in the localization of deformation (Neumann et al. 2000; Célérier et al. 2005). Using numerical models, Célérier et al. (2005) illustrate how high concentrations of heat producing elements in the crust, as reflected in high present-day heat flows, lead to rheological weakening and localization of deformation.

This study demonstrates that the 'passive' margins bounding the Australian continent are not seismically or tectonically passive. Rather, these margins have been actively deformed from the Neogene to Recent in response to stresses transmitted from plate boundaries into the interior of the Indo-Australian Plate.

\section{Implications for the distribution of hydrocarbons}

Neogene-to-Recent intraplate deformation within the Australian continent has had profound and under-recognized effects on hydrocarbon occurrence. On the positive side, neotectonic activity has amplified some hydrocarbon-hosting, fourway dip closed structures, including:

- NNE-trending anticlines of the Carnarvon Basin which have seen Neogene-to-Recent growth including the Barrow Island oilfield located within the Barrow Island inverted anticline (Fig. 9), the giant Scarborough Gas Field located on the Exmouth Plateau (deep-water Carnarvon Basin), and Rough Range, a small oil field located on one of the folds of Australia's NW Cape and the first Australian field to flow oil to the surface.

- Minerva Gas Field of the offshore Otway Basin which is located on an inversion anticline with Neogene-to-Recent growth (Fig. 6).

- Inversion anticline traps of the Gippsland Basin, although there is significant variation in the timing of inversion structures across the Gippsland Basin with some fields such as Barracouta and Flying Fish subject to deformation that continues to the present-day and others such as Turrum subject to little post-mid-Miocene deformation (Dickinson et al. 2001; Power et al. 2003).

However, in general the effects of Neogene-toRecent tectonism have been detrimental to hydrocarbon occurrence. For example, the lack of exploration success in the Torquay and eastern Otway Basins has been ascribed to wells targeting structures formed during Neogene-to-Recent inversion which most likely post-dates the main episode 
of hydrocarbon generation and migration (Trupp et al. 1994; Dickinson et al. 2001; Green et al. 2004). Older structures in such settings may have filled with hydrocarbons but may be prone to seal breach during more recent deformation. Neogene-to-Recent fault reactivation post-charge has been linked to seal breach in both the Penola Trough (Fig. 2) of the Otway Basin (Lyon et al. 2005) and in the Timor Sea (O'Brien \& Woods 1995). Indeed, the prediction of fault orientations likely to be reactivated within the present-day stress field has been incorporated into prospect ranking in the Timor Sea, with a recognition that traps bound by faults likely to have reactivated face an enhanced risk of seal breach (Mildren et al. 2002; Rogers et al. 2008).

Even gentle tilting of pre-existing hydrocarbonfilled structures may change the spill point, leading to partial trap breach without rupturing of the seal. There is, however, the possibility of updip accumulations from breached/spilled accumulations that have received relatively little attention in the Australian context. In general, in Australian basins subject to Neogene-to-Recent tectonism, it is necessary to ascertain in detail the timing of filling of hydrocarbon of traps with respect to deformation. Structures must have formed prior to filling. However, structures that have formed prior to deformation and are hydrocarbon-filled are potentially subject to breach due to fault reactivation or tilting. Gentle anticlinal growth may enhance pre-existing structures without beaching them. Neogeneto-Recent deformation has generally been detrimental to hydrocarbon occurrence and in this context, older structures, not subject to Neogene-to-Recent deformation have lower attendant risk.

The authors acknowledge and appreciate funding for this research from the Australian Research Council. Bob Holdsworth and Emma Nelson are thanked for constructive comments in review.

\section{References}

Allen, T. I., Gibson, G. \& Cull, J. P. 2005. Stress-field constraints from recent intraplate seismicity in southeastern Australia. Australian Journal of Earth Sciences, 52, 217-229.

BArber, P. M. 1988. The Exmouth Plateau deep water frontier: a case history. In: PURCELL, P. G. \& Purcell, R. R. (eds) North West Shelf Australia. Proceedings of the Petroleum Exploration Society of Australia Symposium, Perth, Western Australia, $173-186$.

BARTON, C. M. 1981. Regional stress and structure in relation to brown coal open cuts of the Latrobe Valley, Victoria. Journal of the Geological Society of Australia, 28, 333-339.
Bourman, R. P. \& Lindsay, J. M. 1989. Timing, extent and character of late Cainozoic faulting along the eastern margin of the Mount Lofty Ranges, South Australia. Transactions of the Royal Society of South Australia, 113, 63-67.

Brodie, J. \& White, N. J. 1994. Sedimentary basin inversion caused by igneous underplating: Northwest European continental shelf. Geology, 22, 147-150.

CÉlérier, J., Sandiford, M., Hansen, D. L. \& QUIGLEY, M. 2005. Modes of active intraplate deformation, Flinders Ranges, Australia. Tectonics, 20.

ClARK, D. 2005. A preliminary seismicity model for southwest Western Australia based on neotectonic data. Australian Earthquake Engineering Society Conference, Albury, Earthquake Engineering in Australia. Paper 22. http://www.aees.org.au/Proceedings/2005_Papers/22_ClarkD.pdf.

Clark, D. J. \& Bodorkos, S. 2004. Fracture systems in granite pavement of the eastern Pilbara Craton, Western Australia; indicators of neotectonic activity? Australian Journal of Earth Sciences, 51, 831-846.

Clark, D. J., Dentith, M., Wyrwoll, K.-H., Lu, Y., Dent, V. \& Featherstone, W. 2008. Hyden Fault Scarp, Western Australia: palaeoseismic evidence for repeated Quaternary displacement in an intracratonic setting. Australian Journal of Earth Sciences, 55, 379-395.

Clark, D. J. \& Leonard, M. 2003. Principal stress orientations from multiple focal-plane solutions: new insight into the Australian intraplate stress field. In: HILlis, R. R. \& MÜLleR, R. D. (eds) Evolution and Dynamics of the Australian Plate. Geological Society of Australia, Special Publication, 22, 91-105.

Clark, D. J. \& MCCue, K. 2003. Australian palaeoseismology: towards a better basis for seismic hazard estimation. Annals of Geophysics, 46, 1087-1105.

Coblentz, D. D. \& Richardson, R. M. 1996. Analysis of the South American intraplate stress field. Journal of Geophysical Research, 101(B4), 8643-8658.

Coblentz, D. D., Zhou, S., Hillis, R. R., Richardson, R. M. \& SANDIFORD, M. 1998. Topography, boundary forces, and the Indo-Australian intraplate stress field. Journal of Geophysical Research, 103, 919-931.

Cochran, J. R. 1990. Himalayan uplift, sea level, and the record of Bengal Fan sedimentation at the ODP Leg 116 sites. Proceedings of the Ocean Drilling Program, Scientific Results 116, 397-414.

Crone, A. J., Machette, M. N. \& Bowman, J. R. 1997. Episodic nature of earthquake activity in stable continental regions revealed by palaeoseismicity studies of Australian and North American Quaternary faults. Australian Journal of Earth Sciences, 44, 203-214.

Crone, A. J., De Martini, P. M., Machette, M. N., OKumura, K. \& Prescott, J. R. 2003. Palaeoseismicity of two historically quiescent faults in Australia - implications for fault behaviour in stable continental regions. Bulletin of the Seismological Society of America, 93, 1913-1934.

DE BRoekert, P. \& SANDIford, M. 2005. Buried inset-valleys in the eastern Yilgarn Craton, Western 
Australia: geomorphology, age and allogenic control. Journal of Geology, 113, 471-493.

Denham, D., Alexander, L. G. \& Worotnicki, G. 1979. Stresses in the Australian crust: evidence from earthquakes and in-situ stress measurements. BMR Journal of Australian Geology and Geophysics, 4, 289-295

Dickinson, J. A., Wallace, M. W., Holdgate, G. R., Daniels, J., Gallagher, S. J. \& Thomas, L. 2001. Neogene tectonics in SE Australia: implications for petroleum systems. Australian Petroleum Production and Exploration Association Journal, 41, 37-52.

Dickinson, J. A., Wallace, M. W., Holdgate, G. R., Gallagher, S. J. \& Thomas, L. 2002. Origin and timing of the Miocene-Pliocene unconformity in Southeast Australia. Journal of Sedimentary Research, 72, 288-303.

Doré, A. G., Cartwright, J. A., Stoker, M. S., Turner, J. P. \& White, N. J. 2002. Exhumation of the North Atlantic margin: introduction and background. In: Doré, A. G., CARTwright, J. A., Stoker, M. S., Turner, J. P. \& White, N. J. (eds) Exhumation of the North Atlantic Margin: Timing, Mechanisms and Implications for Petroleum Exploration. Geological Society, London, Special Publications, 196, 1-12.

DunCAN, R. A. \& VARne, R. 1988. The age and distribution of the igneous rocks of Macquarie Island. Papers and Proceedings of the Royal Society of Tasmania 122, Part 1, 45-50.

Gölke, M. \& Coblentz, D. 1996. Origins of the European regional stress field. Tectonophysics, 266, $11-24$.

Green, P. F., Crowhurst, P. V. \& Duddy, I. R. 2004. Integration of the AFTA and (U-Th)/He thermochronology to enhance the resolution and precision of thermal history reconstruction in the Anglesea-1 well, Otway Basin, SE Australia. In: Boult, P. J., Johns, D. R. \& LAnd, S. C. (eds) Eastern Australasian Basins Symposium II, Petroleum Exploration Society of Australia, Special Publication, South Australia, 117-131.

Gurnis, M., Müller, R. D. \& Moresi, L. 1998. Cretaceous vertical motion of Australia and the Australian-Antarctic discordance. Science, 279, 1499-1504.

Harrison, T. M., Copeland, P., Kidd, W. \& Yin, A. 1992. Raising Tibet. Science, 255, 5052, 1663-1670.

HARrowfield, M. \& KeEP, M. 2005. Tectonic modification of the Australian North-West Shelf: episodic rejuvenation of long-lived basin division. Basin Research, 17, 225-239.

Hearty, D. J., Ellis, G. K. \& Webster, K. A. 2002. Geological history of the western Barrow Sub-basin: implications for hydrocarbon entrapment at Woollybutt and surrounding oil and gas fields. In: KeeP, M. \& Moss, S. J. (eds) The Sedimentary Basins of Western Australia 3. Proceedings of the Petroleum Exploration Society of Australia Symposium, Perth, Western Australia, 2002, 577-598.

HILL, K. \& HALL, R. 2003. Mesozoic-Cenozoic evolution of Australia's New Guinea margin in a West Pacific context. Geological Society of America, Special Paper, 372, 265-290.
Hillis, R. R. \& REYNOLDS, S. D. 2000. The Australian Stress Map. Journal of the Geological Society of London, 157, 915-921.

Hillis, R. R. \& ReYnOlds, S. D. 2003. In situ stress field of Australia. In: HILlis, R. R. \& MÜller, R. D. (eds) Evolution and Dynamics of the Australian Plate. Geological Society of Australia, Special Publication, 22, 49-58.

Hocking, R. M. 1988. Regional geology of the northern Carnarvon Basin. In: PURCEll, P. G. \& PURCELl, R. R. (eds) North West Shelf Australia. Proceedings of the Petroleum Exploration Society of Australia Symposium, Perth, Western Australia, 1988, 97-114.

Holdgate, G. R., Wallace, M. W., Gallagher, S. J., Smith, A. J., Keene, J. B., Moore, D. \& SHAFIK, S. 2003. Plio-Pleistocene tectonics and eustacy in the Gippsland Basin, southeast Australia; evidence from magnetic imagery and marine geological data. Australian Journal of Earth Sciences, 50, $403-426$.

Johnston, A. C. 1994. Seismotectonic interpretations and conclusions from the stable continental region seismicity database. The Earthquakes of Stable Continental Regions. Electric Power Research Institute, Report TR-102261-1, 4-1-4-102.

Keep, M., Powell, C. M. \& BAillie, P. W. 1998. Neogene Deformation of the North West Shelf, Australia. In: Purcell, P. G. \& Purcell, R. R. (eds) The Sedimentary Basins of Western Australia 2. Proceedings of the Petroleum Exploration Society of Australia Symposium, Perth, Western Australia, 1988, 81-91.

Krishna, K. S., Bull, J. M. \& Scrutton, R. A. 2001. Evidence for multiphase folding of the central Indian Ocean lithosphere. Geology 29, 8, 715-718.

Lyon, P. J., Boult, P. J., Watson, M. \& Hillis, R. R. 2005. A systematic fault seal evaluation of the Ladbroke Grove and Pyrus traps of the Penola Trough, Otway Basin. Australian Petroleum Production and Exploration Association Journal, 45, 459-476.

Malcolm, R. J., Pott, M. C. \& Delfos, E. 1991. A new tectono-stratigraphic synthesis of the North West Cape area. Australian Petroleum Exploration Association Journal, 31, 154-176.

Massell, C., Coffin, M. F., Mann, P. et AL. 2000. Neotectonics of the Macquarie Ridge Complex, Australia-Pacific plate boundary. Journal of Geophysical Research, B, Solid Earth and Planets 105, 6, 13457-13480.

MClaren, S., Dunlap, W. J., SAndiford, M. \& McDougall, I. 2002. Thermochronology of high heat-producing crust at Mount Painter, South Australia: Implications for tectonic reactivation of continental interiors. Tectonics 21, doi:10.1029/ 2000 TC001275.

Mildren, S. D. 1997. The Contemporary Stress Field of Australia's North West Shelf and Collision Related Tectonism. Ph.D. thesis, Department of Geology and Geophysics, The University of Adelaide, Australia.

Mildren, S. D., Hillis, R. R. \& Kaldi, J. 2002. Calibrating predictions of fault seal reactivation in the Timor Sea. Australian Petroleum Production and Exploration Association Journal, 42, 187-202.

Müller, R. D., Lim, V. S. L. \& ISERN, A. R. 2000. Late Tertiary tectonic subsidence on the northeast 
Australian passive margin: response to dynamic topography? Marine Geology, 162, 337-352.

Nelson, A. W. 1989. Jabiru field - Horst, sub-horst or inverted graben? Australian Petroleum Exploration Association Journal, 29, 176-194.

Nelson, E. J. \& Hillis, R. R. 2005. In situ stresses of the West Tuna area, Gippsland Basin. Australian Journal of Earth Sciences, 52, 299-313.

Nelson, E. J., Hillis, R. R., Reynolds, S. D. \& Mildren, S. D. 2006. Present-day state-of-stress of southeast Australia. Australian Petroleum Production and Exploration Association Journal, 46, 283-305.

Neumann, N., SAndiford, M. \& Foden, J. 2000. Regional geochemistry and continental heat flow: Implications for the origin of the South Australian heat flow anomaly. Earth and Planetary Science Letters, 183, 170-120.

O'Brien, G. W. \& Woods, E. P. 1995. Hydrocarbon related diagenetic zones (HRDZs) in the Vulcan Sub-basin, Timor Sea; recognition and exploration implications. Australian Petroleum Exploration Association Journal, 35, 220-252.

O'Brien, G. W., Morse, M., Wilson, D., Quaife, P., Colwell, J., Higgins, R. \& Foster, C. B. 1999. Margin -scale, basement-involved compartmentalisation of Australia's North West Shelf: a primary control in basin-scale rift, depositional and reactivation histories. Australian Petroleum Production and Exploration Association Journal, 39, 40-63.

OllieR, C. D. 1978. Tectonics and geomorphology of the Eastern Highlands. In: DAVIES, J. L. \& Williams, M. A. (eds) Landform Evolution in Australia, ANU Press, 5-47.

PACKHAM, G. 1996. Cenozoic SE Asia; reconstructing its aggregation and reorganization. In: HALL, R. \& BLundell, D. J. (eds) Tectonic Evolution of Southeast Asia. Geological Society London, Special Publications, 106, 123-152.

PAN, Y. \& KIDD, W. S. F. 1992. Nyainqentanglha shear zone; a late Miocene extensional detachment in the southern Tibetan Plateau. Geology, 20, 9, $775-778$.

Petterson, M. G., Neal, C. R., Mahoney, J. J., Kroenke, L. W., Saunders, A. D., Babbs, T. L., Duncan, R. A., Tolia, D. \& McGrail, B. 1997. Structure and deformation of north and central Malaita, Solomon Islands; tectonic implications for the Ontong Java Plateau-Solomon arc collision, and for the fate of oceanic plateaus. Tectonophysics, 283, $1-4,1-33$

Power, M. R., Hill, K. C. \& Hoffman, N. 2003. Structural inheritance, stress rotation, overprinting and compressional reactivation in the Gippsland Basin-Tuna 3D seismic dataset. Australian Petroleum Production and Exploration Association Journal, 43, 197-221.

Quigley, M., Cupper, M. \& SAndiford, M. 2006. Quaternary faults of southern Australia: palaeoseismicity, slip rates and origin. Australian Journal of Earth Sciences, 53, 285-301.

Quigley, M., SANDIFORD, M., FifIELD, K. \& Alimanovic, A. 2007. Bedrock erosion and relief production in the northern Flinders Ranges, Australia.
Earth Surface Processes and Landforms, 32, doi: 10.1002/esp. 1459.

REYNOLDS, S. D. \& HiLlis, R. R. 2000. The in situ stress field of the Perth Basin, Australia. Geophysical Research Letters, 27, 3421-3424.

Reynolds, S. D., Coblentz, D. \& Hillis, R. R. 2002. Tectonic forces controlling the regional intraplate stress field in continental Australia: results from new finite-element modelling. Geophysical Research Letters, 107(B7).

Reynolds, S. D., Coblentz, D. \& Hillis, R. R. 2003. Influences of plate-boundary forces on the regional intraplate stress field of continental Australia. In: Hillis, R. R. \& MÜller, R. D. (eds) Evolution and Dynamics of the Australian Plate. Geological Society of Australia, Special Publication, 22, 59-70.

Reynolds, S. D., Mildren, S. D., Hillis, R. R. \& MEYER, J. J. 2006. Constraining stress magnitudes using petroleum exploration data in the CooperEromanga Basins, Australia. Tectonophysics, 415, $123-140$.

RICHARDSON, R. M. 1992. Ridge forces, absolute plate motions, and the intraplate stress field. Journal of Geophysical Research, 97, 11739-11748.

Rogers, C., VAN Ruth, P. J. \& Hillis, R. R. 2008. Fault reactivation in the Port Campbell Embayment with respect to carbon dioxide sequestration, Otway Basin, Australia. Geological Society London, Special Publication, 306, 201-214.

SANDIFORD, M. 2003a. Geomorphic constraints on the late Neogene tectonics of the Otway Ranges. Australian Journal of Earth Sciences, 50, 69-80.

SANDIFORD, M. 2003 b. Neotectonics of southeastern Australia: linking the Quaternary faulting record with seismicity and in situ stress. In: HILlis, R. R. \& MüLleR, D. R. (eds) Evolution and Dynamics of the Australian Plate. Geological Society of Australia, Special Publication, 22, 107-119.

Sandiford, M., Wallace, M. W. \& Coblentz, D. 2004. Origin of the in situ stress field in southeastern Australia. Basin Research, 16, 325-338.

Schneider, C. L., Hill, K. C. \& Hoffman, N. 2004. Compressional growth of the Minerva anticline, Otway Basin, Southeast Australia-evidence of oblique rifting. Australian Petroleum Production and Exploration Association Journal, 44, 463-480.

Sharp, N. C. \& Wood, G. R. 2004. Casino Gas Field, offshore Otway Basin, Victoria-the appraisal story and some stratigraphic enlightenment. In: BoulT, P. J., Johns, D. R. \& LAND, S. C. (eds) Eastern Australasian Basins Symposium II, Petroleum Exploration Society of Australia, Special Publication, South Australia, 1-11.

Shuster, M. W., Eaton, S., Wakefield, L. L. \& Koosterman, H. J. 1998. Neogene tectonics, greater Timor Sea, offshore Australia: implications for trap risk. Australian Petroleum Production and Exploration Association Journal, 38, 351-379.

SuTHERLAND, R. 1996. Transpressional development of the Australia-Pacific boundary through southern South Island, New Zealand; constraints from Miocene-Pliocene sediments, Waiho-1 borehole, South Westland, New Zealand. Journal of Geology and Geophysics 39, 2, 251-264. 
TokAReV, V., SAndiford, M. \& Gostin, V. 1999. Landscape evolution in the Mount Lofty Ranges: implications for regolith development. In: TAYLOR, G. \& PAIN, C. (eds) New Approaches to an Old Continent, 3rd Australian Regolith Conference Proceedings, Regolith '98. Cooperative Research Centre for Landscape Evolution and Mineral Exploration, 127-134.

Trupp, M. A., Spence, K. W. \& Gidding, M. J. 1994. Hydrocarbon prospectivity of the Torquay Sub-basin, offshore Victoria. Australian Petroleum Exploration Association Journal, 34, 479-494.

Turner, J. P. \& Williams, G. A. 2004. Sedimentary basin inversion and intra-plate shortening. Earth Science Reviews, 65, 277-304.

Twidale, C. R. \& Bourne, J. A. 1975. Geomorphological evolution of part of the eastern Mount Lofty Ranges, South Australia. Transactions of the Royal Society of South Australia, 99, 197-210.

Twidale, C. R. \& Bourne, J. A. 2004. Neotectonism in Australia: its expressions and implications. Geomorphologie: relief, processus, environnement, 3, 179-194.

VAn DE GrafF, W. J. E., Denmann, P. D. \& Hocking, R. M. 1976. Emerged Pleistocene marine terraces on Cape Range, Western Australia. Geological Survey of Western Australia. Annual Report for 1975, 62-70.

van Ruth, P., Hillis, R. R. \& Tingate, P. 2004. The origin of overpressure in the Carnarvon Basin, Western Australia: implications for pore pressure prediction. Petroleum Geoscience, 10, $247-257$.
Veevers, J. J. \& Powell, C. McA. 1984. Dextral shear within the eastern Indo-Australian plate. In: Veevers, J. J. (eds) Phanerozoic Earth History of Australia. Claredon Press, Oxford, 102-103.

WALCOTt, R. I. 1998. Modes of oblique compression: late Cainozoic tectonics of the South Island of New Zealand. Reviews of Geophysics 36, 1-26.

Wessel, P. \& Kroenke, L. 2000. Ontong Java Plateau and late Neogene changes in Pacific Plate motion. Journal of Geophysical Research, B, Solid Earth and Planets 105, 12, 28, 255-28, 277.

Williams, A. F. \& Poynton, D. J. 1985. The geology and evolution of the South Pepper hydrocarbon accumulation. Australian Petroleum Exploration Association Journal, 25, 235-247.

Woods, E. P. 1988. Extensional structures of the Jabiru Terrace, Vulcan Sub-basin. In: Purcell, P. G. \& Purcell, R. R. (eds) North West Shelf Australia. Proceedings of the Petroleum Exploration Society of Australia Symposium, Perth, Western Australia, 1988, 311-330.

Ziegler, P. A., van Wees, J. \& Cloetingh, S. 1998. Mechanical controls on collision related compressional intraplate deformation. Tectonophysics, 300 , $103-129$

Zoback, M. D., Apel, R., Baumgärtner, J., ET AL. 1993. Upper-crustal strength inferred from stress measurements to $6 \mathrm{~km}$ depth in the KTB borehole. Letters to Nature, 365, 633-635.

ZoвACK, M. L. 1992. First- and second-order patterns of stress in the lithosphere: the world stress map project. Journal of Geophysical Research, 97, $11703-11728$. 